\title{
Pemodelan Sebaran Tumpahan Minyak di Perairan Karawang, Jawa Barat
}

\author{
Muh. Dandi Firmansyah, Aris Ismanato*, Sri Yulina Wulandari, Rikha Widiaratih, \\ Azis Rifai, Warsito Atmodjo
}

Departemen Oseanografi, Fakultas Perikanan dan Ilmu Kelautan, Universitas Diponegoro Jl. Prof. H. Soeadarto S.H, Tembalang, Semarang, Jawa Tengah 50275 Indonesia

Email : aris.ismanto@gmail.com

\begin{abstract}
Abstrak
Perairan Karawang merupakan salah satu perairan yang dilintasi Alur Laut Kepulauan Indonesia (ALKI) dimana kapal-kapal besar dan kapal tanker melintasi area perairan ini. Pada bagian utara Perairan Karawang juga terdapat kegiatan pengeboran migas (minyak dan gas) sumur bor milik salah satu perusahaan minyak dan gas nasional, sehingga Perairan Karawang dan sekitarnya mempunyai resiko yang tinggi terhadap tumpahan minyak. Tujuan penelitian ini adalah untuk memperkirakan luasan pola persebaran tumpahan minyak mentah (crude oil) akibat kebocoran sumur bor di perairan Karawang dan wilayah perairan di sekitarnya. Penelitian ini dibagi menjadi dua tahapan, yaitu tahap survei lapangan dan tahap pemodelan numerik. Pemodelan numerik terdiri dari pemodelan arus, sebaran tumpahan minyak, dan nasib (fate) minyak setelah tumpah yang masing-masing dimodelkan menggunakan model matematika dua dimensi Penelitian ini menggunakan metode kuantitatif dan untuk menentukan lokasi pengukuran menggunakan metode purposive sampling. Trayektori Sebaran tumpahan minyak mentah (crude oil) dominan bergerak dari sumur bor pada koordinat $107^{\circ} 37^{\prime} 32.52^{\prime \prime} \mathrm{E}$ dan $06^{\circ} 5^{\prime} 39^{\prime \prime} \mathrm{S}$ menuju ke arah barat, bergerak dari Perairan Karawang menuju Perairan Bekasi. Hal itu terjadi karena peristiwa minyak tumpah terjadi musim timur, yakni arus dominan bergerak dari arah timur dan tenggara menuju ke arah barat dan barat laut. Daerah terdampak tumpahan minyak ini meliputi Kabupaten Karawang dan Kabupaten Bekasi, khususnya wilayah Perairan Kecamatan Muara Gembong dengan luasan sebaran tumpahan minyak sekitar
\end{abstract} $249.91 \mathrm{~km}^{2}$.

Kata Kunci : Sebaran Tumpahan Minyak, Trayektori, Perairan Karawang

\section{Abstract \\ Modeling of Oil Spill Distribution in Karawang Waters, West Java}

Karawang waters is one of the waters crossed by the Indonesian Archipelago Sea Channel (ALKI) where large ships and tankers cross this water area. In the northern part of Karawang Waters, there is also oil and gas (oil and gas) drilling activities which are owned by one of the national oil and gas companies, so that the Karawang waters and surrounding areas have a high risk of oil spills. The purpose of this study was to estimate the extent of the distribution pattern of crude oil spills due to leakage of wells in the waters of Karawang and the surrounding waters. This research was divided into two stages, namely the field survey stage and the numerical modeling stage. Numerical modeling consists of modeling the flow, distribution of oil spills, and the fate of oil after spilling, each of which is modeled using 2 dimension mathematical model. This study uses quantitative methods and to determine the location of measurements using the purposive sampling method. Trajectory The dominant distribution of crude oil spills moves from the wellbore at

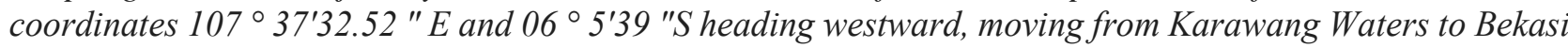
Waters. This happened because the oil spill event occurred in the east season, which is the dominant current moving from east and southeast to west and northwest. Areas affected by the oil spill include Karawang Regency and Bekasi Regency, especially the waters of the Muara Gembong District with an area of distribution of oil spills around $249.91 \mathrm{~km}^{2}$.

Keywords: Oil Spill Spreading, Trajectory, Karawang Waters 



\section{PENDAHULUAN}

Perairan Karawang terletak di Kabupaten Karawang, Provinsi Jawa Barat yang dilintasi Alur Laut Kepulauan Indonesia (ALKI) dimana kapalkapal besar dan kapal tanker melintasi area perairan ini. Pada bagian utara Perairan Karawang juga terdapat kegiatan migas (minyak dan gas) yang cukup ragam dan tingkat risikonya terhadap potensi kejadian tumpahan minyak (Setyonugroho et al., 2019). Pada tanggal 12 Juli sumur bor milik salah satu perusahaan minyak dan gas nasional di Perairan Karawang mengalami kebocoran sehingga menyebabkan terjadinya tumpahan minyak sekitar 3.000 barrel per hari. Tumpahan minyak tersebut mencemari pesisir Karawang dan daerah sekitarnya seperti Pantai Alam Baru, area Galangan Kapal Sungai Buntu, kawasan pesisir Tanjung Pakis, Tambaksari, dan Cemara Jaya, bahkan sampai ke daerah Kepulauan Seribu (Samosir et al., 2019).

Tumpahan minyak di laut dapat dengan cepat menyebar ke daerah Perairan yang lebih luas akibat pengaruh dari adanya dinamika laut (arus, gelombang, dan pasang surut) dan adanya pergerakan angin (wind forcing) (Fingas, 2001). Kondisi ini diperparah dengan kekuatan angin yang berhembus cukup kencang di Perairan Karawang dengan kecepatan rata-rata sekitar 30$35 \mathrm{~km} / \mathrm{jam}$ dengan lama tiupan sektitar 5 -7 jam per hari. Angin yang berhembus di sekitar Perairan Karawang menjadi faktor utama pembangkit gelombang dan arus di sekitar Perairan Karawang (RDTR Tanjung Baru, 2003). Selain angin sebagai faktor utama pembangkit gelombang dan arus, adanya pergerakan arus yang kuat di Perairan Karawang, arus pada perairan Karawang relatif kuat karena berhadapan langsung dengan Laut Jawa. Faktor-faktor oseanografi itulah yang mengakibatkan tumpahan minyak cepat meluas di sekitar Perairan Karawang yang apabila tidak segera ditangani dapat menimbulkan berbagai macam permasalahan baik permasalahan lingkungan maupun sosial. Permasalahanpermasalahan akibat pencermaran tumpahan minyak tersebut dapat menghambat laju pertumbuhan ekonomi masyarakat di sekitar pesisir, terutama warga nelayan yang menggantungkan hidupnya dari sumber kekayaan laut.(Samosir et al., 2019).

Seperti diketahui bahwa sebaran tumpahan minyak di Perairan Karawang mempunyai dampak negatif bagi kelangsungan hidup manusia, baik dari segi lingkungan (ekologi), sosial, maupun ekonomi. Secara ekologi tumpahan minyak di Perairan Karawang menyebabkan sekitar $2.400 \mathrm{Ha}$ hutan mangrove di sekitar pantai rusak akibat tumpahan minyak (Nopiana, 2020). Dampak sosial dari tumpahan minyak di Perairan Karawang menyebabkan sekitar 7.782 nelayan tersebar di 12 desa Karawang terdampak oleh pencemaran minyak, sehingga kesulitan dalam melakukan pencarian ikan di laut (Samosir et al., 2019). Dampak ekonomi tumpahan minyak Perairan Karawang menurunkan nilai produksi perikanan Kabupaten Karawang, dampak tersebut terjadi pada wilayah Kecamatan Tirtamulya, Cilamaya Wetan, Cilamaya Kulon, Lemahabang, Tempuran, Kutawaluyo, Pedes, Cilebar, Cibuaya, Tirtajaya, Batujaya, dan Pakisjaya. Total kerugian secara ekonomi dari segi perikanan di wilayah Karawang dan sekitarnya mencapai sekitar Rp. 144.531.699 untuk perikanan laut dan Rp. 336.568.215 untuk perikanan tambak (Samosir et al., 2019).

Penelitian ini dilakukan untuk memodelkan persebaran tumpahan minyak di Perairan Karawang mengingat besarnya dampak yang dapat ditimbulkan, baik dari segi lingkungan (ekologi), sosial, dan ekonomi oleh pencemaran tumpahan minyak sehingga resiko yang ditimbulkan apabila terjadi kasus serupa di kemudian hari dapat diminimalisir. Penelitian ini diharapkan mampu mewakili kondisi yang sebenarnya di lapangan agar upaya penanggulangan akibat tumpahan minyak lebih cepat, efektif, dan efisien.

\section{MATERI DAN METODE}

Materi yang digunakan pada penelitian ini terdiri dari data yang digunakan dalam penelitian dan alat- alat yang digunakan selama pengambilan dan pengolahan data. Pelaksanaan penelitian dibagi menjadi tiga tahap, yaitu tahap studi literatur, tahap pengambilan dan pengumpulan data penelitian, dan tahap pengolahan data. Data yang digunakan dalam penelitian ini dibagi menjadi menjadi dua, yaitu data primer dan data sekunder. Data primer merupakan data yang diperoleh hasil dari pengukuran langsung di lapangan yang terdiri dari pengukuran data arus laut, suhu permukaan laut, dan data salinitas perairan. Adapun data sekunder merupakan data penunjang dari data primer dalam proses pengolahan data yang didapatkan dari instansi terkait dan sumber dari website. Data sekunder terdiri dari data pasang 
surut, angin dari ECMWF, properties minyak, data lokasi tumpahan minyak, dan peta batimetri.

Metode penelitian merupakan langkahlangkah ilmiah yang ditempuh untuk menghasilkan data dengan maksud dan tujuan tertentu. Metode kunatitatif merupakan metode yang memenuhi kaidah-kaidah ilmiah yang bersifat objektif, sistematis, terukur, terencana, dan rasional dalam suatau penelitian. Penelitian ini menggunakan metode kuantitatif karena data yang digunakan berupa data angka dan analisis datanya menggunakan pendekatan statistik (Sugiyono, 2009).

Penelitian ini juga dilakukan survei lapangan untuk mendapatkan data-data penunjang selama penelitian, yaitu berupa data angka yang diukur dengan menggunakan instrumentasi khusus disetiap parameternya. Metode penentuan lokasi pengambilan data arus, salinitas, dan suhu permukaan laut menggunakan purposive sampling method. Menurut Sugiyono (2009), purposive sampling method merupakan metode penentuan lokasi pengambilan data berdasarkan pertimbangan- pertimbangan tertentu untuk mencapai suatu tujuan penelitian. Pengukuran arus laut menggunakan ADCP Multi Cell ArgonautXR. Sedangkan pengukuran data salinitas menggunakan Refraktometer RHB 32 ATC dan data suhu permukaan laut menggunakan Flow Watch FL-03 JDC.

\section{HASIL DAN PEMBAHASAN}

Model hidrodinamika dijalankan untuk mensimulasi arus di Perairan Kerawang. Arus di perairan pantai dipengaruhi oleh pasang surut dan angin yang bertiup di atas laut. Kondisi arus laut sangat penting untuk diketahui di Perairan Karawang karena sangat mempengaruhi pola sebaran tumpahan minyak (Sinurat et al., 2016). Gelombang laut sebenarnya juga mempengaruhi arus laut di dekat pantai, tapi dalam model yang telah dijalankan pengaruh arus yang dibangkitkan oleh gelombang dianggap kecil. (Ismanto et.al, 2008).

Gerak sirkulasi arus di perairan pantai yang dangkal dapat diasumsikan sebagai aliran masa air yang bercampur sempurna (homogen) mulai dari permukaan laut sampai kedasar perairan dan pengaruh angin di permukaan diasumsikan mencapai dasar laut. Oleh karena itu persamaan model yang dipakai adalah persamaan yang diintegrasikan terhadap kedalaman. Dalam model ini air laut dianggap sebagai fluida yang tak mampu mampat (incompresible fluid). (DHI, 2006). Model hidrodinamika tersebut terdiri dari (Ismanto et.al, 2018) : Persamaan kontinuitas, dimana dalam persamaan ini debit air akan dimasukkan. Persamaan kekekalan momentum, dimana pengaruh angin dan pasang surut akan diperhatikan. (Ismanto et.al, 2008). Persamaan

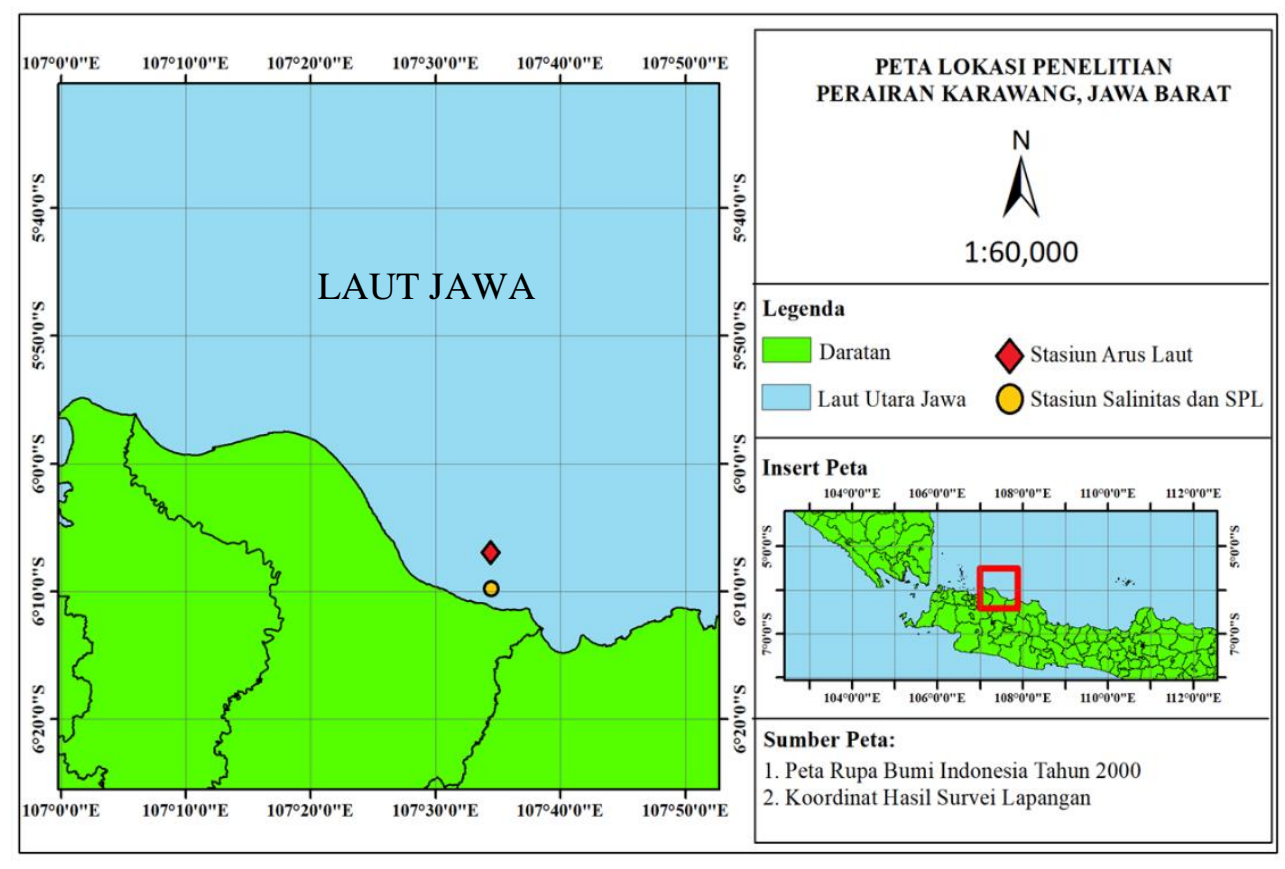

Gambar 1. Lokasi Penelitian 
Kontinuitas sebagaimana dimaksudkan di atas dirumuskan sebagai berikut (Kowalik et.al, 1993):

$$
\frac{\partial \xi}{\partial t}+\frac{\partial U}{\partial x}+\frac{\partial V}{\partial y}=Q_{s}
$$

Persamaan Kekekalan Momentum dirumuskan sebagai berikut:

$$
\begin{aligned}
& \mid \frac{\partial U}{\partial t}+\frac{U}{H} \frac{\partial U}{\partial x}+\frac{V}{H} \frac{\partial U}{\partial y}+g H \frac{\partial \xi}{\partial x}+r U \frac{\sqrt{U^{2}+V^{2}}}{H^{2}} \\
& -A_{h}\left(\frac{\partial^{2} U}{\partial x^{2}}+\frac{\partial^{2} U}{\partial y^{2}}\right)=\lambda W_{x} \sqrt{W_{x}^{2}{ }^{+} W_{y}^{2}} \\
& \frac{\partial V}{\partial t}+\frac{U}{H} \frac{\partial V}{\partial x}+\frac{V}{H} \frac{\partial V}{\partial y}+g H \frac{\partial \xi}{\partial y}+r V \frac{\sqrt{U^{2}+V^{2}}}{H^{2}} \\
& -\Lambda_{h}\left(\frac{\partial^{2} V}{\partial x^{2}}+\frac{\partial^{2} V}{\partial y^{2}}\right)=\lambda W_{y} \sqrt{W_{x}^{2}+W_{y}^{2}}
\end{aligned}
$$

Keterangan : $\mathrm{x}, \mathrm{y}=$ koordinat ruang bertambah besar ke arah timur dan utara (m); $\mathrm{u}, \mathrm{v}=$ kecepatan arus arah-x dan arah-y (m/detik); $\mathrm{U}=$ transpor dalam arah sb-x ( $\mathrm{m}^{2} /$ detik $) ; \mathrm{V}=$ transpor dalam arah sb-y $\left(\mathrm{m}^{2} /\right.$ detik); $\mathrm{t}=$ parameter waktu (detik); $\xi=$ elevasi dari permukaan laut terhadap muka air rata-rata $(\mathrm{m}) ; \mathrm{g}=$ percepatan gravitasi bumi $\left(\mathrm{m} / \operatorname{detik}^{2}\right) ; \mathrm{H}=$ kedalaman aktual $=\mathrm{h}+\rho(\mathrm{m}) ; \mathrm{h}=$ kedalaman laut yang tetap $(\mathrm{m}) ; \mathrm{r}=$ koefisien gesekan dasar; $A_{h}=$ koefisien gesekan eddy horisontal ( $\mathrm{m}^{2} /$ detik); $\lambda=$ koefisien gesekan angin; $\mathrm{W}_{\mathrm{x}}, \mathrm{W}_{\mathrm{y}}=$ kecepatan angin arah- $\mathrm{x}$ dan arah- $\mathrm{y}$ (m/detik); $\mathrm{Q}_{\mathrm{s}}=$ debit $\left(\mathrm{m}^{3} /\right.$ detik$)$

Model hidrodinamika tersebut diselesaikan dengan menggunakan metode semi implisit dua langkah dimana variabel-variabelnya dihitung pada deretan sel ruang pada setiap langkah waktu. Metoda ini dipilih karena dalam pemilihan langkah waktu simulasi tidak bergantung pada kriteria stabilitas Courant - Friedrich-Lewy (CFL) seperti pada metoda eksplisit, sehingga memori komputer dapat dihemat dan simulasinya menjadi lebih ekonomis. Hasil simulasi numerik dilakukan penyederhanaan beberapa parameter kompleks pada perairan yang dijadikan domain agar mempermudah pelaksanaan simulasi numerik. Cahyana (2005) mengemukakan pendapat bahwa untuk melakukan simulasi diperlukan penyederhanaan sistem dengan menjaga stabilitas komponen utama. Data-data yang digunakan pada model ini adalah peta situasi dan batimetri, data pasang surut, angin rata-rata, dan kondisi fisik di sekitar lokasi.

Model tumpahan minyak di laut pada dasarnya dapat dipandang sebagai penyebaran materi terlarut dalam air, yaitu: (a) dengan adanya kecepatan dari aliran fluida mengakibatkan minyakterdispersi secara langsung oleh aliran fluida. Proses gerak ini disebut adveksi, (b) Proses difusi turbulen berhubungan dengan variasi kecepatan dalam arah penampang melintang aliran oleh adanya gerak turbulensi. Kedua proses tersebut antara udara-laut serta tumpahan minyak dirumuskan dalam persamaan berikut (Letter, et.al., 2003):

$\frac{\partial C}{\partial t}+u \frac{\partial C}{\partial x}+v \frac{\partial C}{\partial y}=\frac{\partial}{\partial x}\left(D_{x} \frac{\partial C}{\partial x}\right)+\frac{\partial}{\partial y}\left(D_{y} \frac{\partial C}{\partial y}\right)+\alpha_{1} C+\alpha_{2}$

Keterangan : $C=$ konsentrasi Minyak, $\mathrm{kg} / \mathrm{m}^{3} ; t=$ waktu, detik; $u=$ kecepatan aliran arah $\mathrm{x}, \mathrm{m} / \mathrm{d} ; v=$ kecepatan aliran arah y, $\mathrm{m} / \mathrm{d} ; D_{x}=$ koefisien dispersi arah x, $\mathrm{m}^{2} / \mathrm{d} ; D_{y}=$ koefisien dispersi arah $\mathrm{y}, \mathrm{m}^{2} / \mathrm{d} ; \alpha_{1}=$ koefisien suku sumber, $1 / \mathrm{sec} ; \alpha_{2}=$ konsentrasi seimbang dari suku sumber $\mathrm{kg} / \mathrm{m}^{3} / \mathrm{d}=$ $-\alpha_{1} \mathrm{C}_{\mathrm{eq}}$

Model tumpahan minyak ini disimulasikan sesuai dengan skenario yang didesain sama dengan skenario simulasi model arus seperti telah diuraikan di muka, karena model hidrodinamika dan model tumpahan minyak dijalankan secara bersamaan atau biasa disebut model kopel dari dua model tersebut.

\section{Simulasi Model Hidrodinamika}

Berdasarkan hasil pemodelan hidrodinamika pola pergerakan arus di Perairan Karawang mempunyai perbedaan pasa saat kondisi purnama (spring tide) dan kondisi perbani (neap tide) karena perairan Karawang termasuk kedalam jenis arus pasut yang dipengaruhi oleh kondisi pasang surut pada lokasi tersebut. Selain itu, bentuk morfologi dasar perairan juga sangat mempengaruhi pola pergerakan arus pada lokasi tersebut. Kecepatan arus cenderung lebih besar pada daerah perairan yang dalam, sedangkan pada saat mendekat daerah 
pantai (perairan dangkal) kecepatan arusnya akan semakin kecil. Pada Perairan Karawang juga mengalami turbulensi atau pusaran air, yakni saat purnama kondisi laut surut menuju pasang, perbani kondisi pasang menuju surut, perbani kondisi surut terendah, dan perbani kondisi surut menuju pasang perairan. Turbulensi atau pusaran tersebut terjadi di sekitar Perairan dekat pantai Kecamatan Cilebar, Pedes, Cibuaya, Tirtajaya, dan Paksijaya Kabupaten Karawang. Turbulensi tersebut terjadi karena adanya pendangkalan dasar perairan pada lokasi tersebut. Menurut Kusumawati (2016), turbulensi merupakan gaya gesek baik yang terjadi antara air dan dasar laut maupun air laut dengan air laut.

Perbedaan pola arus di Perairan Karawang sangat dipengaruhi oleh kondisi pasang surut pada lokasi tersebut, sehingga kecepatan arusnya akan berbeda pada saat kondisi purnama dan perbani. Menurut Gross (1972), arus pasut merupakan arus yang ditimbulkan oleh adanya perbedaan tekanan hidrostatik yang disebabkan oleh adanya dinamika pasang surut. Kecepatan arus ada saat kondisi purnama akan lebih besar daripada kecepatan arus pada kondisi perbani. Hal tersebut terjadi karena pada saat purnama posisi bulan berada paling dekat dengan bumi, sehingga pengaruh gaya gravitasi bulan kuat dan menyebabkan terbentuknya arus yang kuat pada kondisi purnama. Pada kondisi perbani posisi bulan berada paling jauh dari bumi, sehingga pengaruh gravitasi bulan juga lemah dan menyebabkan terbentuk arus yang lebih lemah daripada kondisi purnama. Kecepatan arus maksimum pada saat purnama kondisi pasang tertinggi sebesar $0,487 \mathrm{~m} / \mathrm{s}$ dan kecepatan arus maksimum pada saat perbani kondisi pasang tertinggi sebesar $0,405 \mathrm{~m} / \mathrm{dt}$. Hal tersebut sesuai dengan pernyataan Wibisono (2005), bahwa pada saat kondisi purnama tunggang pasut (selisih/beda pasang tertinggi dengan surut terendah) lebih besar daripada saat kondisi perbani, sehingga volume massa air mengalir pada saat purnama lebih besar dibandingkan saat kondisi perbani.

\section{Verifikasi Data Model dengan Data Lapangan}

Verifikasi digunakan untuk mengetahui tingkat kesalahan suatu simulasi model yang sudah dibuat. Verifikasi pada penelitian ini menggunakan RMS (Root Mean Square) yang bertujuan untuk menunjukkan kecocokan dua jenis data (Evans, 1993); (Ismanto et al., 2019). RMS membandingkan antara kecapatan arus hasil simulasi model dengan kecepatan arus hasil pengukuran lapangan yang mendapatkan hasil RMS sebesar $4.06 \%$. Nilai error yang relatif kecil tersebut disebabkan karena perbedaan antara kecepatan arus hasil simulasi model tidak terlalu jauh berbeda dengan kecepatan arus hasil pengukuran langsung di lapangan yang terlihat pada grafik perbandingan antara kecepatan arus hasil pemodelan dengan kecepatan arus lapangan ditampilkan pada Gambar 10.

\section{Simulasi Model Tumpahan Minyak}

Hasil simulasi tumpahan minyak di Perairan Karawang dan sekitarnya mengikuti pola pergerakan arus pada lokasi tersebut. Hasil model tumpahan minyak mentah (crude oil) ditampilkan dalam waktu tumpahan per minggu hingga tanggal 31 Juli 2019. Hal tersebut bertujuan untuk mengetahui daerah yang terkena dampak tumpahan minyak di setiap minggunya. Arah dan pergerakan sebaran tumpahan minyak di Perairan Karawang dipengaruhi oleh faktor osenaografi, yakni pergerakan arus permukaan laut yang dibangkitkan oleh angin dan pasang surut, dengan faktor osenaografi tersebut seiring bertambahnya waktu akan menambah luas permukaan minyak yang tumpah. Tampak pada Gambar 11 - Gambar 13 sebaran tumpahan minyak meluas setiap minggunya.

Lokasi tumpahan minyak akibat bocornya sumur bor milik salah satu perusahaan minyak dan gas nasional berada pada koordinat $6^{\circ} 5^{\prime} 39^{\prime \prime} \mathrm{S}$ dan $107^{\circ} 37^{\prime} 32.52^{\prime \prime} \mathrm{E}$. Waktu terjadinya tumpahan tersebut terjadi pada tanggal 12 Juli 2019. Tumpahan minyak di Perairan Karawang dominan bergerak dari arah tenggara (Perairan Karawang) menuju ke arah barat laut (Perairan Muara Gembong Bekasi dan sekitarnya). Hal tersebut disebabkan karena arus Perairan Karawang dominan begerak dari arah Tenggara menuju Barat Laut pada saat kondisi pasang, baik pada saat purnama (spring tide) dan maupun perbani (neap tide) dengan kecepatan arus diatas $0.4 \mathrm{~m} / \mathrm{dt}$. Berdasarkan kondisi tersebut arah pegerakan tumpahan minyak dominan bergarak dari arah Tenggara menuju arah Barat Laut.

Pada minggu pertama (12 Juli 2019 - 18 Juli 2019) setelah terjadi terjadi tumpahan, terlihat bahwa trayektori tumpahan minyak bergerak dari lokasi sumur bor menuju ke arah Barat Laut dan mulai mencemari daerah perairan Karawang. Daerah yang tercemar meliputi wilayah perairan Karawang bagian barat, yakni daerah pesisir Kecamatan Cibuaya, Kabupaten Karawang. 


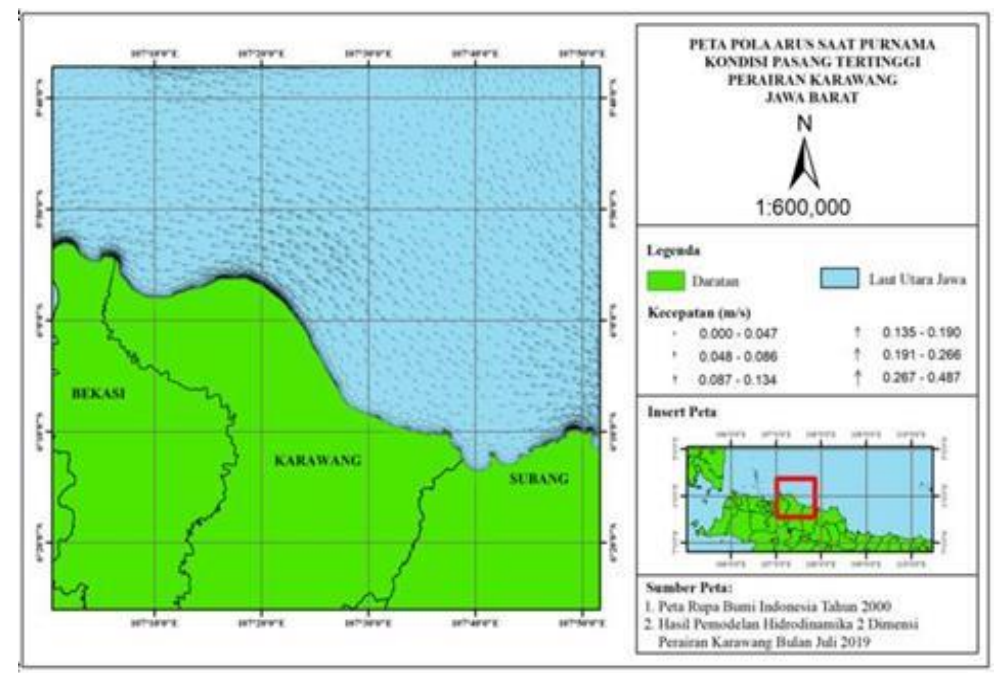

Gambar 2. Pola Arus Saat Purnama Kondisi Pasang Tertinggi Perairan Karawang

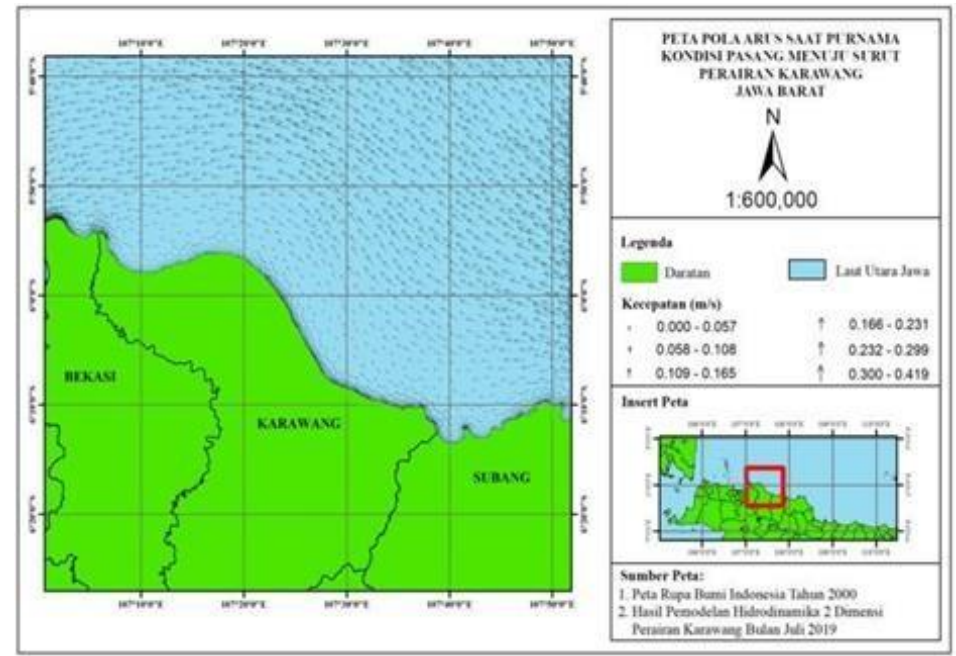

Gambar 3. Pola Arus Saat Purnama Kondisi Pasang Menuju Surut Perairan Karawang

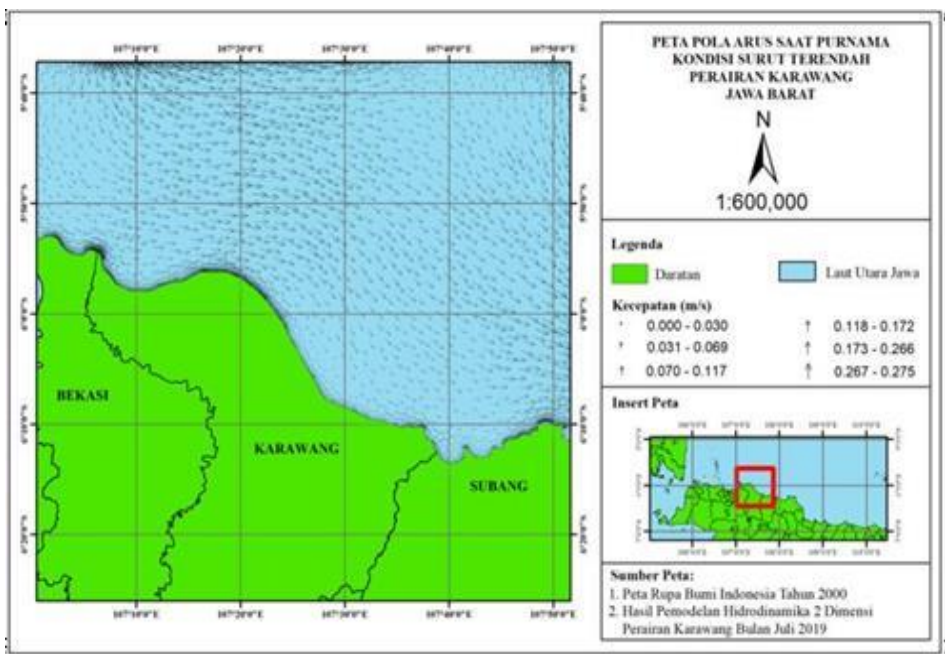

Gambar 4. Pola Arus Saat Purnama Kondisi Surut Terendah Perairan Karawang 


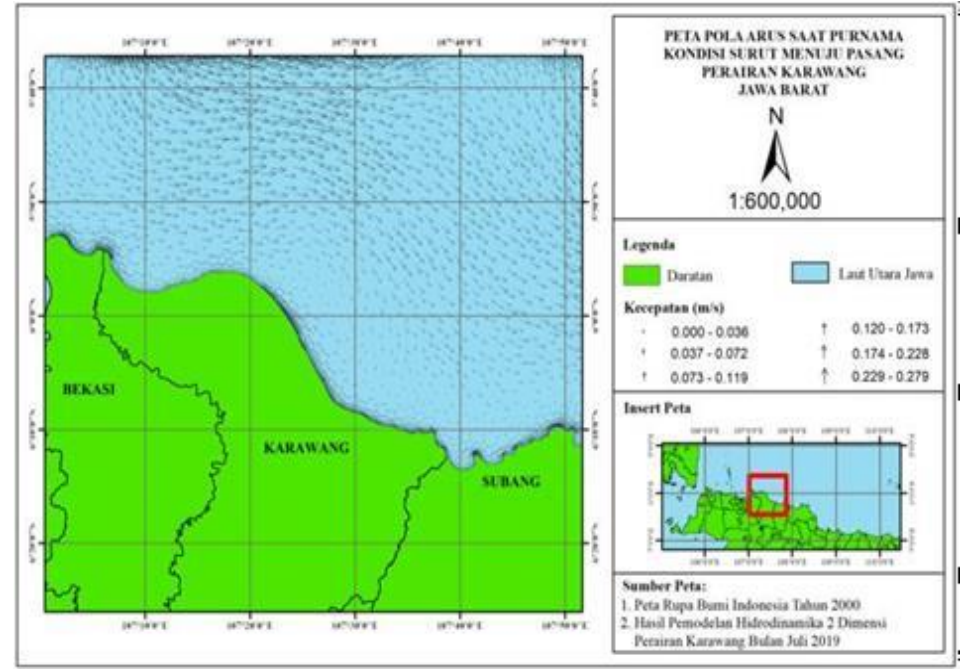

Gambar 5. Pola Arus Saat Purnama Kondisi Surut Menuju Pasang Perairan Karawang

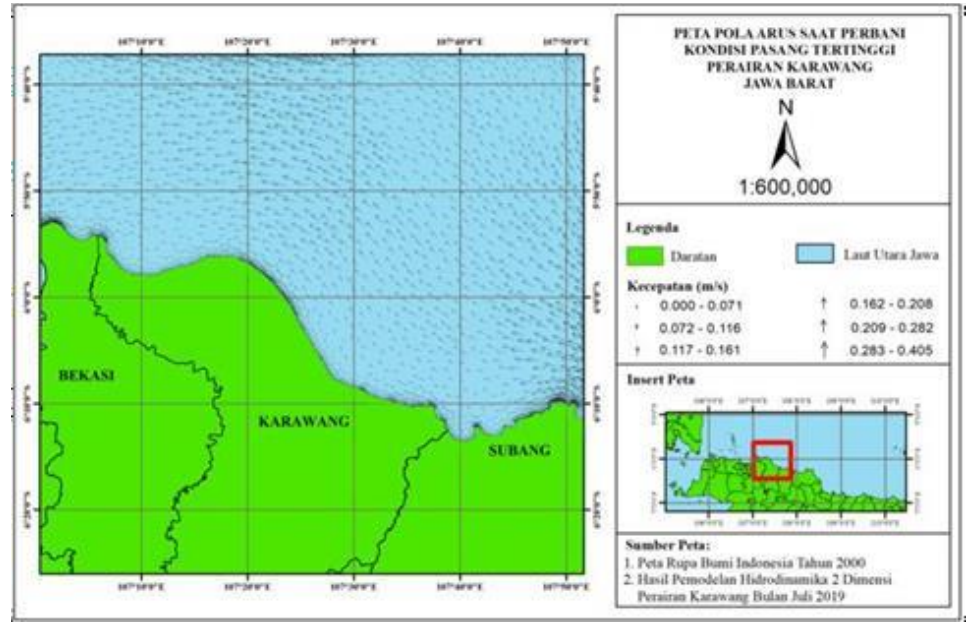

Gambar 6. Pola Arus Saat Perbani Kondisi Pasang Tertinggi Perairan Karawang

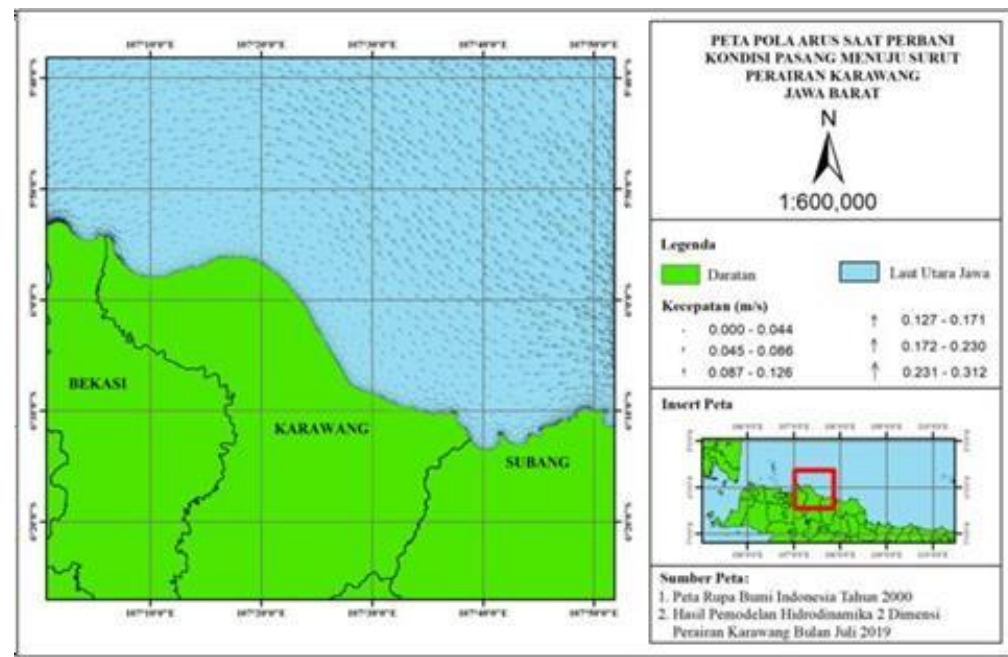

Gambar 7. Pola Arus Saat Perbani Kondisi Pasang Menuju Surut Perairan Karawang 


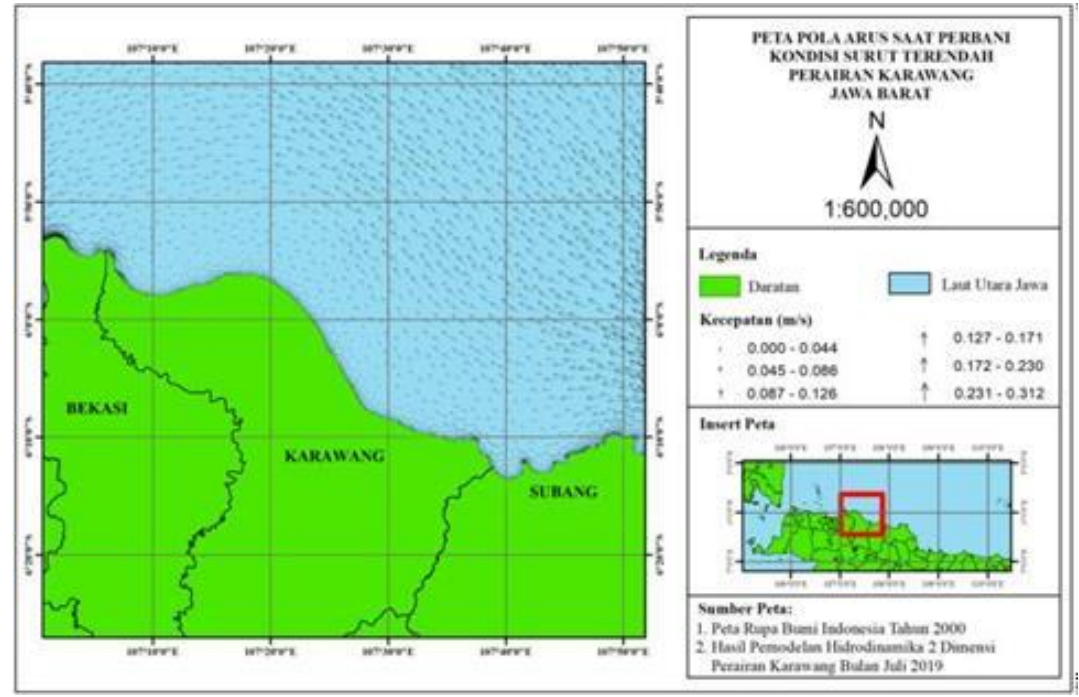

Gambar 8. Pola Arus Saat Perbani Kondisi Surut Terendah Perairan Karawang

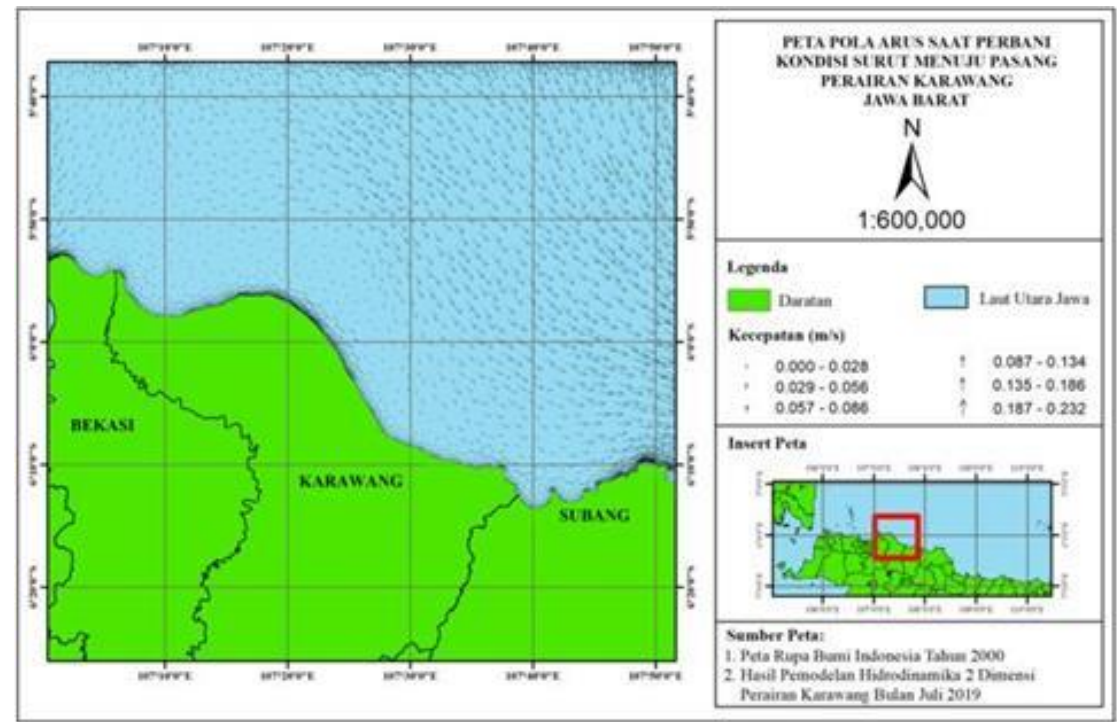

Gambar 9. Pola Arus Saat Perbani Kondisi Surut Menuju Pasang Perairan Karawang

Luasan sebaran tumpahan minyak pada minggu pertama sekitar $100.73 \mathrm{~km} 2$. Hal ini sesuai dengan pernyataan dari Dharmawan H. Samsu, Direktur Hulu Pertamina dalam konferensi pers di Kantor Pusat Pertamina pada tanggal 25 Juli 2019, menyatakan bahwa sebaran tumpahan minyak sudah mencapai ke daerah pantai Karawang arah barat pada tanggal 18 Juli 2019.

Pada minggu kedua (19-25 Juli 2019), trayektori sebaran tumpahan semakin meluas bergerak dari sumur bor menuju ke arah barat laut dan mulai menuju Perairan Bekasi dengan area terdampak yang semakin bertambah. Daerah yang tercemar meliputi wilayah perairan Karawang bagian barat, yakni daerah pesisir Kecamatan Cibuaya dan pesisir Kecamatan Pedes, Kabupaten Karawang. Selain itu, sebaran minyak juga sudah mulai memasuki Perairan Kecamatan Muara Gembong.

Kabupaten Bekasi. Luasan sebaran tumpahan minyak pada minggu kedua sekitar $186.61 \mathrm{~km}^{2}$. Hal ini sesuai dengan pernyataan dari Dwi Sawung, Anggota Wahana Lingkungan Hidup Indonesia dalam konferensi pers pada tanggal 1 Agustus 2019 menyatakan, bahwa sebaran tumpahan minyak pada tanggal 23 Juli 2019 sudah mulai memasuki Perairan Bekasi. 


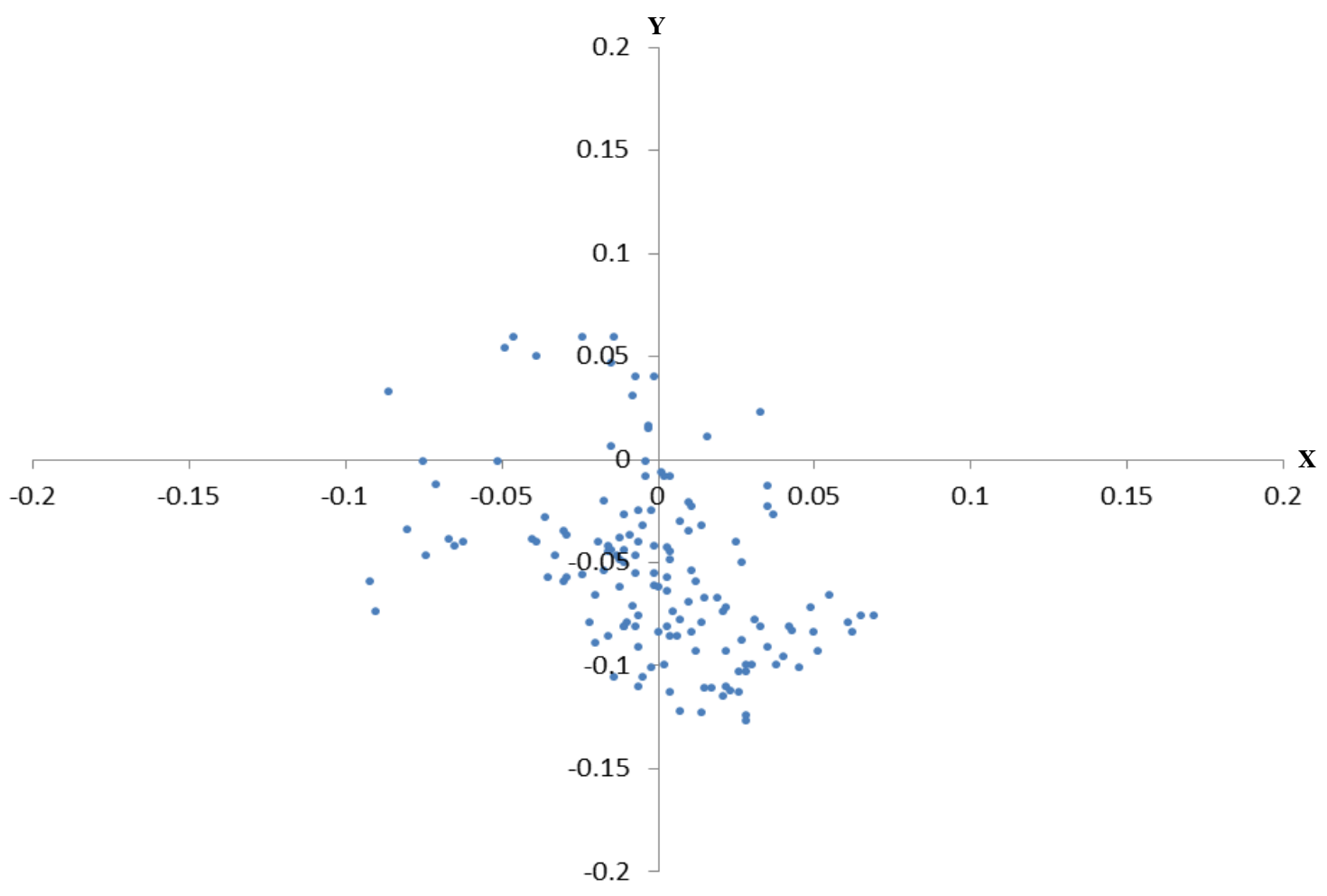

Gambar 10. Scatter Plot Arus Lapangan Perairan Karawang

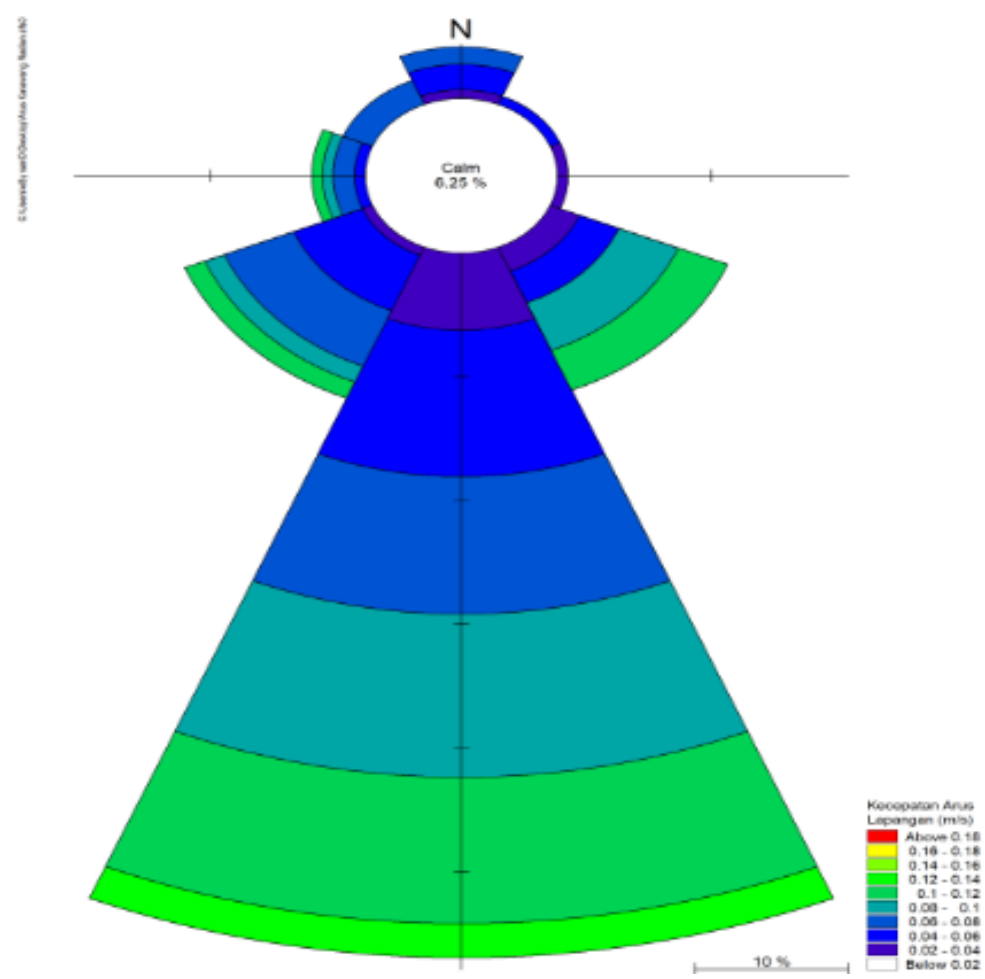

Gambar 11. Currentrose pada tanggal 29-30 Juli 2019 Perairan Karawang 


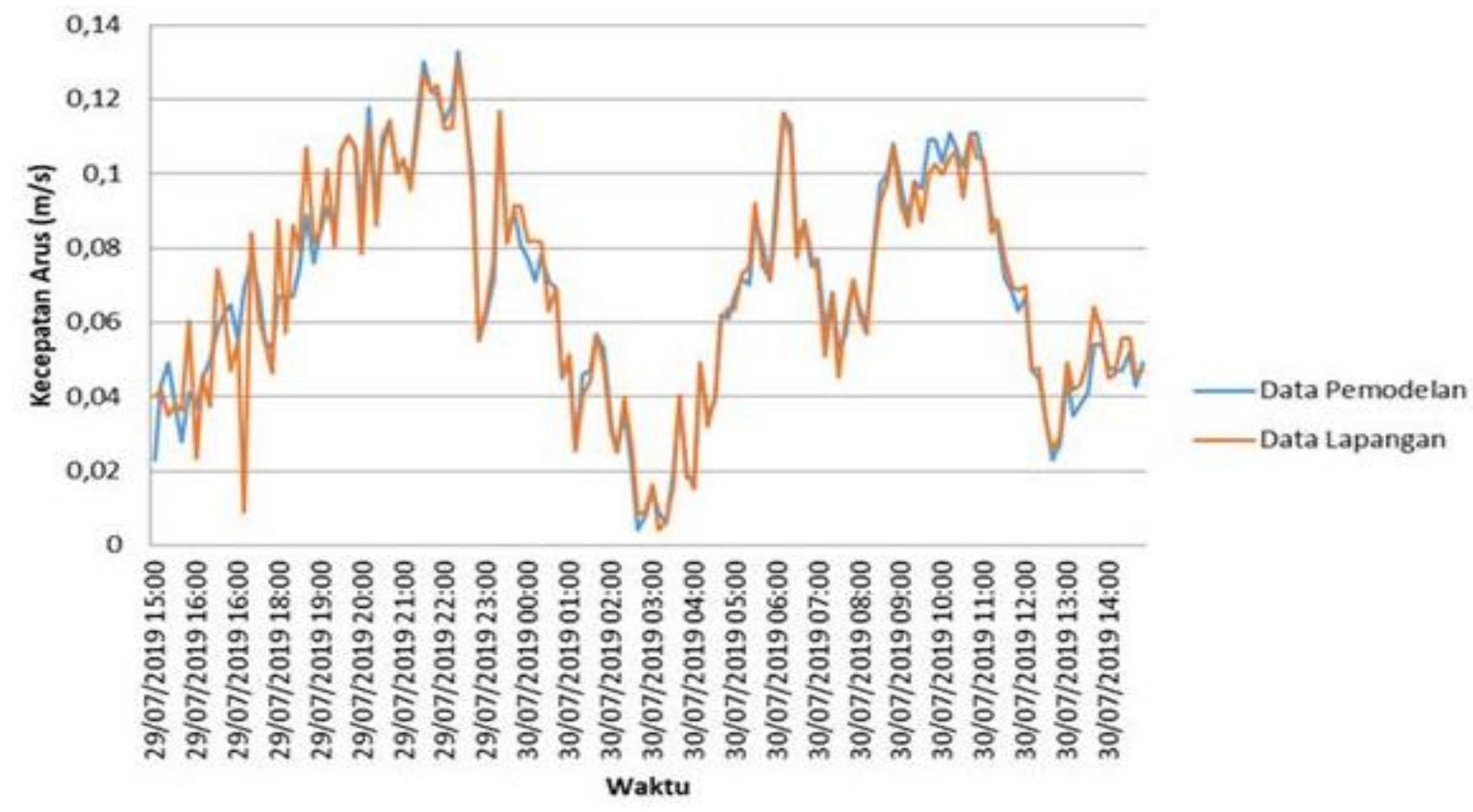

Gambar 12. Grafik Perbandingan Data Arus Pemodelan dengan Data Arus
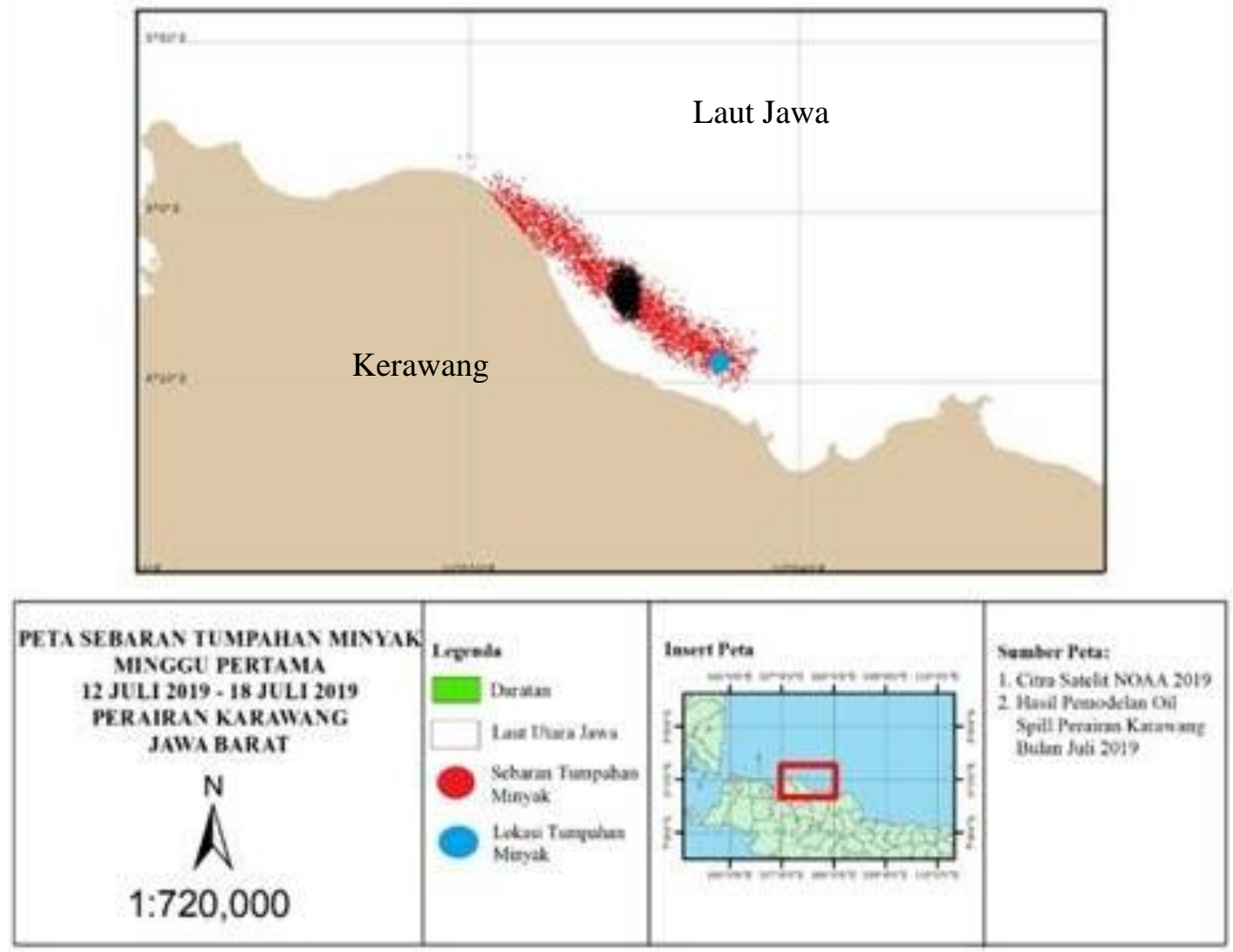

Gambar 13. Simulasi Tumpahan Minyak Minggu Pertama (12 Juli 2019 - 18 Juli 2019)

Keterangan :Warna Hitam Warna hitam menunjukkan density/ketebalan dari tumpahan minyak 

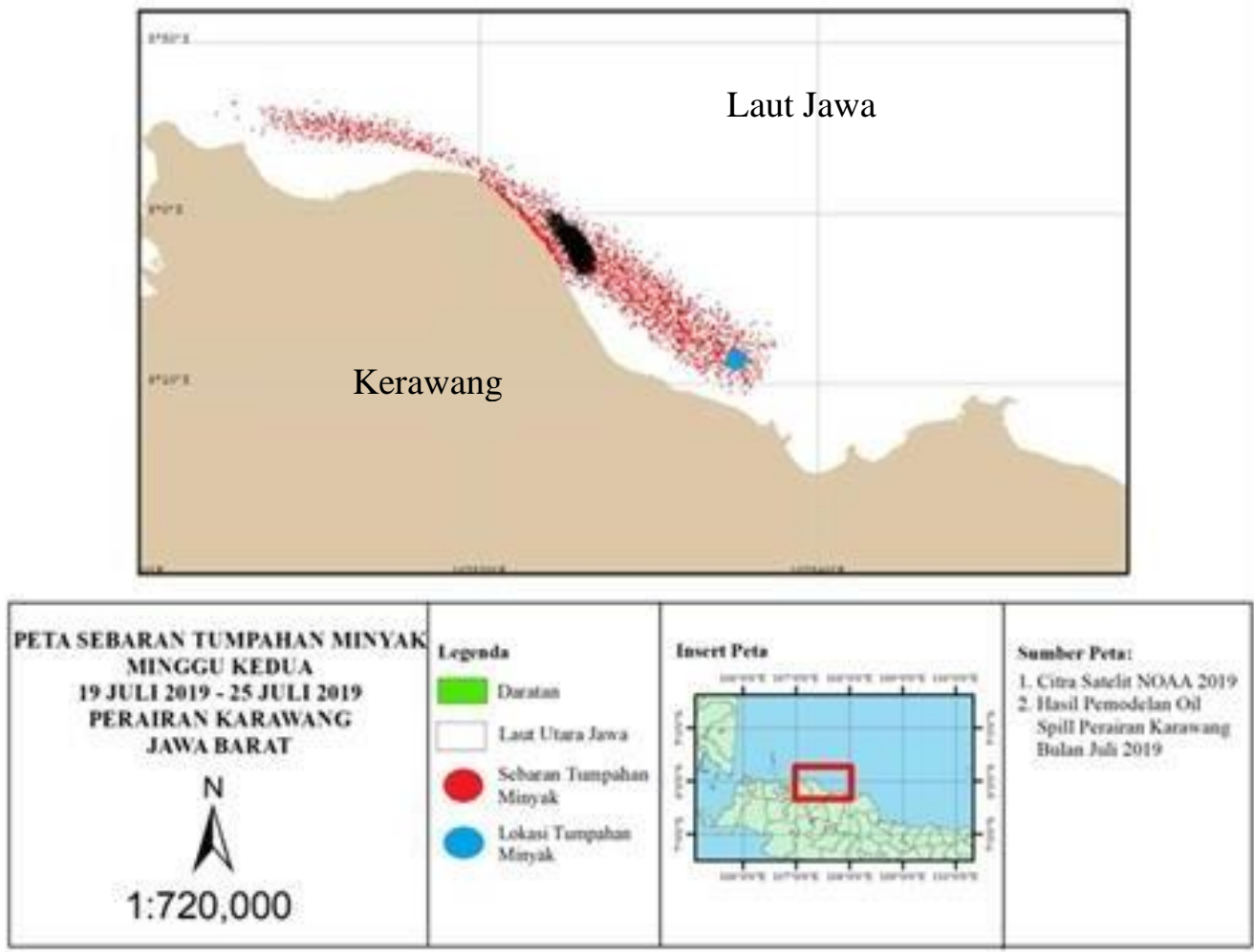

Gambar 14. Simulasi Tumpahan Minyak Minggu Kedua (19 Juli 2019 - 25 Juli 2019)

Keterangan :Warna Hitam Warna hitam menunjukkan density/ketebalan dari tumpahan minyak

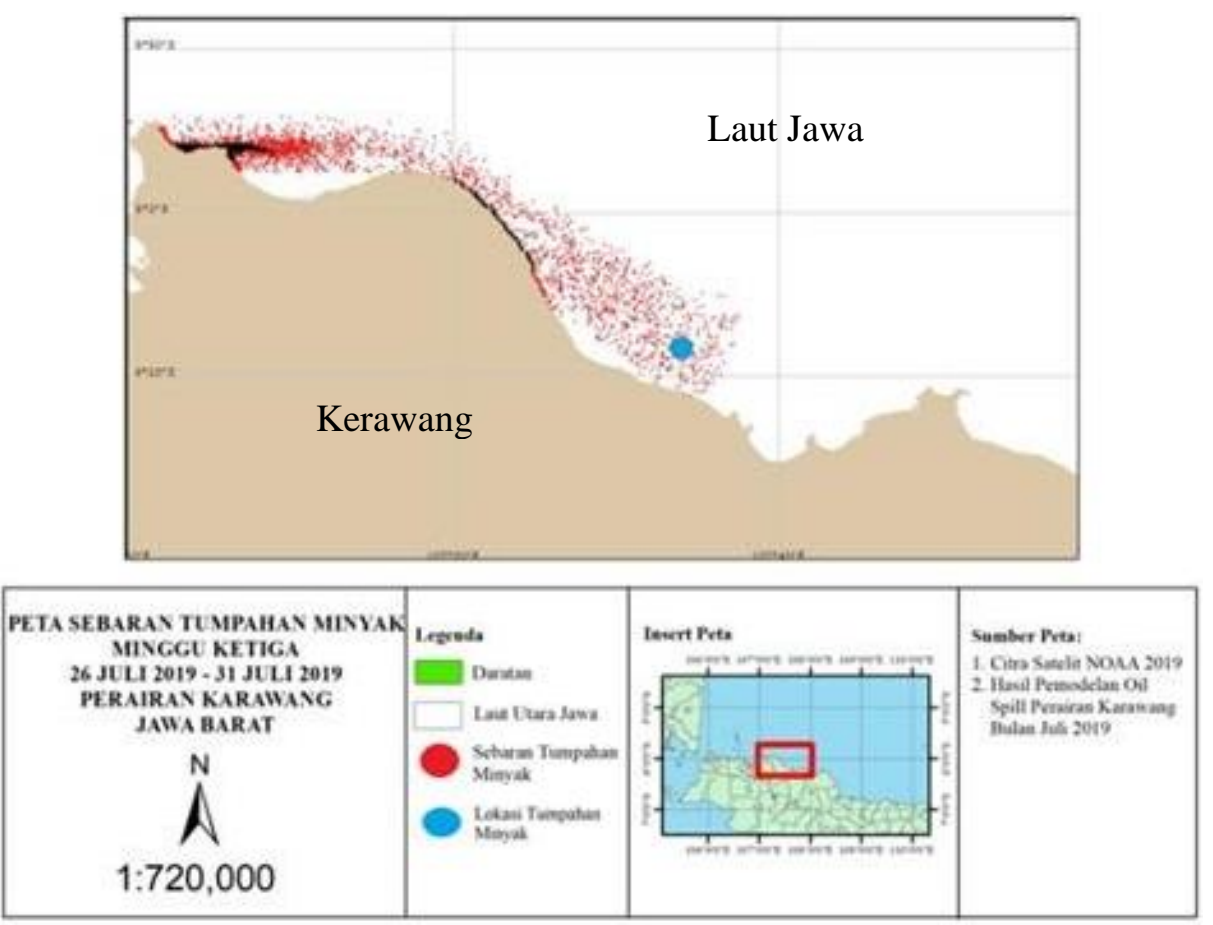

Gambar 15. Simulasi Tumpahan Minyak Minggu Ketiga (26 Juli 2019 - 1 Juli 2019)

Keterangan :Warna Hitam Warna hitam menunjukkan density/ketebalan dari tumpahan minyak 
Pada minggu ketiga (26 Juli 2019 - 31 Juli 2019), trayektori sebaran tumpahan semakin meluas bergerak dari sumur bor menuju ke arah barat laut dan sudah mencapai daerah Perairan Bekasi dengan area terdampak yang semakin bertambah. Daerah yang tercemar meliputi wilayah perairan Karawang bagian barat, yakni daerah pesisir Kecamatan Cibuaya, pesisir Kecamatan Pedes, pesisir Kecamatan Cilebar, dan pesisir Kecamatan Pakisjaya Kabupaten Karawang Kabupaten Karawang. Selain itu, sebaran minyak juga sudah mencapai daerah pantai Perairan Kecamatan Muara Gembong, Kabupaten Bekasi. Luasan sebaran tumpahan minyak pada minggu kedua sekitar $249.91 \mathrm{~km} 2$. Hal ini sesuai dengan pernyataan dari Djoko Siswanto, Pelaksana Tugas (Plt) Direktur Jenderal Minyak dan Gas Bumi (Dirjen Migas) Kementerian ESDM dalam konferensi pers, menyatakan bahwa sebaran tumpahan minyak mengarah ke arah barat per 29 Juli 2019, di mana ada delapan desa di Karawang dan Bekasi yang terdampak dari tumpahan minyak tersebut.

\section{KESIMPULAN}

Hasil pemodelan tumpahan minyak di Perairan Karawang menggunakan dapat disimpulkan bahwa trayektori sebaran tumpahan minyak mentah (crude oil) dominan bergerak dari sumur bor menuju ke arah barat laut, bergerak dari Perairan Karawang menuju Perairan Bekasi. Hal itu terjadi karena peristiwa minyak tumpah terjadi pada tanggal 12 Juli 2019 yang menurut pembagian musim merupakan musim timur. Pada musim timur ini arus dominan bergerak dari arah timur dan tenggara menuju ke arah barat dan barat laut. Daerah pesisir yang terdampak tumpahan minyak ini meliputi Kabupaten Karawang (Kecamatan Cilebar, Pedes, Cibuaya, dan Pakisjaya) dan Kabupaten Bekasi, khususnya wilayah di Perairan Kecamatan Muara Gembong dengan luasan sebaran tumpahan minyak (oil spill) sekitar 249.91 $\mathrm{km} 2$.

\section{DAFTAR PUSTAKA}

Cahyana, C. 2005. Model Hidrodinamika Laut. Buletin Limbah, 9(2):17-18

Clark, R.B. 1989. Marine Pollution. Clarendon Press, Oxford.

Danish Hydraulic Institute Water and Enviroment [DHI]. 2006. Mike 21 HD Scientific Documentation. DHI Water \& Environment. Denmark.Gross, M.G. 1972. Oceanography a
View The Earth. Prentice Hall International Inc. London, UK.

Evans, G.P. 1993. A Framework for Marine and Estuarine model Specification in the UK Foundation of Water Research. UK.

Fingas, M. 2000. The Basics of Oil Spill Cleanup 2nd ed. Lewis publishers Boca: Canada.

Ismanto, A., Widada, S., \& Susiati, H. 2008. Kajian Dispersi Termal dalam Rencana Pembangunan PLTN Muria: Sebuah Analisis, Jurnal Geoaplika, 3(3):143-150

Ismanto, A., Ismunarti, D.H., Sugianto, D.N., Maisyarah, S., Subardjo, P., Suryoputro, A.D.S., \& Siagian, H. 2019. The Potential of Ocean Current as Electrical Power Sources Alternatives in Karimunjawa Islands Indonesia. Advances in Science, Technology and Engineering Systems Journal. 4(6):126133.

International Tanker Owners Pollution Federation Limited [ITOPF]. 2010. About Marine Spills. http://www.itopf.com [4 April 2019].

Krisdiantoro. 2012. Model Sebaran Tumpahan Minyak di Perairan Indramayu, Jawa Barat. Fakultas Perikanan dan Ilmu Kelautan. Institut Pertanian Bogor, Bogor.

Letter J., Teeter, A.M., \& Donnel, B.P. 2003. Users Guide to SED2D Version 4.5. US Army Engineer Research and Development Center. Waterways Experiment Station. Coastal and Hydraulics Laboratory. New York. 184 pp

Kowalik, Z., dan Murty, T.S.: 1993, Numerical Modelling of Ocean Dynamics. World Scientific. Singapore.

Kusumawati, I. 2016. Pemodelan Dinamika Arus Perairan Indonesia yang disebabkan oleh Angin. Jurnal Perikanan Tropis. 3(1):1-10.

Nopiana, M., Yulianda, F., Sulistiono., \& Fahrudin, A. 2020. Coastal rehabilitation through the mplementation of government policy: Case study in Karawang Regency, West Java, Indonesia. Jurnal Perspektif Pembiayaan dan Pembangunan Daerah. 7(4):359-374.

Nurjaya, I. W., Surbakti, H., \& Gunawan, A.W. 2016. Kondisi Oseanografi dan Model HidroDinamika Perairan Sekitar Pulau Yamdena dan Pulau Selaru, Kabupaten Maluku Tenggara Barat. Pusat Kajian Sumberdaya Pesisir dan Lautan Institut Pertanian Bogor, Bogor.

Rencana Detail Tata Ruang Kabupaten Karawang [RDTR]. 2003. Analisis Rencana Detail Tata Ruang Tanjung Baru. Dinas Cipta Karya, Karawang. 
Samosir, D.M., Salim, I., Amanda, Y., Hasanah, A.N.C., Sitompul, J.R., \& Ridho, T.M.M. 2013. Karawang Oil Spill: A Brief Story of A Catastrophic Oil Spill. Esri Indonesia's Emergency Spatial Support Center, Jakarta.

Setyonugrogo, A., Damar, A., \& Nurjaya, I.W. 2019. Kajian Risiko Penangulangan Tumpahan Minyak: Studi Kasus di Laut Jawa Bagian Barat. Journal of Natural Resources and Environmental Management. (3):826-839.
Sugiyono. 2009. Metode Penelitian Kuantitatif, Kualitatif dan R\&D. Alfabeta, Bandung.

Sunirat, M.E.B., Ismanto, A., \& Hariyadi. 2016. Analisis Pola Sebaran Tumpahan Minyak Mentah (Crude Oil) dengan Pendekatan Model Hidrodinamika dan Spill Analysis di Perairan Balongan, Indramayu, Jawa Barat. Jurnal Oseanografi. 5(2):218-226.

Wibisono, M.S. 2005. Pengantar Ilmu Kelautan. Grasindo,Jakarta. 